\title{
10. NANNOPLANKTON STRATIGRAPHY OF LEG 67 DRILL SITES ${ }^{1}$
}

\author{
Nikita Muzylöv, Geological Institute, U.S.S.R. Academy of Sciences, Moscow, U.S.S.R.
}

\section{INTRODUCTION}

On DSDP Leg 67, drilling was done at seven sites (494-500) during the months of May and June, 1979 (Fig. 1). These sites form a transect across the Middle America Trench off Guatemala. Nannoplankton were recovered at each site; biostratigraphic results are summarized in Table 1. The nannoplankton zonation is based on that of Bukry $(1973 ; 1975)$. Stratigraphic distribution of taxa are shown in Figures 2 through 9.

\section{SITE RESULTS}

\section{Site 494 (Holes 494 and 494A)}

Located at the foot of the landward slope, this site was planned to examine the validity of the accretionaryprism-trench-slope hypothesis. Three defects of the section concern this study: (1) the low percentage of core recovery, (2) the high degree of disturbance, and (3) many intervals are without nannoplankton or contain very poor nannoflora. Nevertheless, this site is the most interesting one of the Leg, owing to its unexpected stratigraphy (Fig. 2).

Quaternary. Emiliania huxleyi/Gephyrocapsa oceanica Zones, Crenalithus doronicoides Zone (Samples 494-1-1, 30-32 cm to 494-4,CC; Samples 494A-1-1, $40-42 \mathrm{~cm}$ to $494 \mathrm{~A}-16, \mathrm{CC})$. Nannoflora are relatively diverse and numerous in diatomaceous mud and mudstone of Hole 494 and in Cores 1 to 8 of Hole 494A. Beneath Core 494A-9 there are very rare samples with poor nannoflora only.

The assemblage of the Emiliania huxleyi/Gephyrocapsa oceanica Zones consists of $G$. oceanica (rare to common), small Gephyrocapsa and Emiliania (rare to common), Helicosphaera carteri, Calcidiscus leptoporus, Emiliania ovata, and E. annula (Samples 494-1-1, $30-32 \mathrm{~cm}$ to $494-4, C C$; Samples $494 \mathrm{~A}-1-1,40-42 \mathrm{~cm}$ to 494A-2-5, 30-32 cm). The lower Pleistocene Crenalithus doronicoides Zone (Samples 494A-4,CC to 494A-16,CC) contains a similar assemblage but without $G$. oceanica.

Upper Pliocene. Discoaster brouweri Zone (Samples 494A-17-1, 44-46 $\mathrm{cm}$ and 494A-17-2, 44-46 cm). The scanty assemblage of this interval includes $D$. brouweri (few), small Gephyrocapsa and Emiliania, and Helicosphaera carteri.

Core 18 to Section 494A-20-4 are barren.

Middle Miocene. ?Discoaster exilis Zone (Samples $494 \mathrm{~A}-20-4,125 \mathrm{~cm}$ to $494 \mathrm{~A}-22-3,20-22 \mathrm{~cm}$ ). The upper

\footnotetext{
${ }^{1}$ Aubouin, J., von Huene, R., et al,, Init. Repts. DSDP, 67: Washington (U.S. Govt. Printing Office).
}

limit of the Miocene sediments is marked by a distinct lithologic contact. In the bluish gray mottled clay of this part of the section only five samples contain moderately well preserved nannoplankton. The most rich of these is Sample 494A-21-2, 10-12 cm, including Helicosphaera aff. rhomba, Coccolithus pelagicus s.1., Cyclicargolithus floridanus (common), Reticulofenestra pseudoumbilica, Sphenolithus moriformis, Discoaster deflandrei (very rare), D. aff. kugleri (very rare), D. aff. bellus (very rare), and some other forms. This interval most likely belongs to the Discoaster exilis Zone. The distinguishing feature of the assemblage is extreme Discoaster rarity.

Middle Miocene. Nannotetrina quadrata/Discoaster sublodoensis Zones (Samples 494A-22-3, $67 \mathrm{~cm}$ to 494A$27-2,8-9 \mathrm{~cm}$ ). A distinct change of lithology marks the boundary between the overlying Miocene sediments and the Eocene beneath. The list of autochthonous taxa of the dark gray Eocene mudstone includes 29 species. The preservation of nannoplankton is good in the upper part of the mudstone, down to Core 25 approximately, and moderate to poor below, because of recrystallization. The co-occurrence of Discoaster barbadiensis, D. saipanensis, D. sublodoensis, D. gemmifer, D. strictus, Calcidiscus formosus, Chiasmolithus solitus, C. grandis, Helicosphaera pappilata, Sphenolithus obtusus, $S$. radians, and Reticulofestra umbilica limits this interval to the Nannotetrina quadrata Zone, although its lower part, beginning with Sample 494A-26-3, 10-13 cm, does not contain $D$. saipanensis and may already belong to the middle Eocene Discoaster sublodoensis Zone.

Mixed age-Upper Cretaceous and middle Eocene (Samples 494A-28-1, 10-11 cm to 494A-29-1, $85 \mathrm{~cm}$ ). This interval is represented by dark olive gray mudstone and bluish limestone. Sample 494A-28-1, 10-11 cm includes strongly recrystallized Upper Cretaceous (Maestrichtian) Micula decussata, M. aff. mura, Arkhangelskiella cymbiformis, Cribrosphaera ehrenbergii, Watznaueria barnesae. The next sample (494A-29-1, 33-34 $\mathrm{cm})$ contains an Eocene assemblage similar to that just mentioned. Whether this mixing is a result of drilling or of tectonic disturbance is unclear.

Drilling breccia of Cores 30 to 32 are barren.

\section{Site 495}

This site is on the seaward slope of the Trench; it is the reference site for the stratigraphy of oceanic sequences entering the Middle America Trench off Guatemala. The first 18 cores of Hole 495 are represented by biogenic hemipelagic mud.

Quaternary. Gephyrocapsa oceanica Zone, Crenalithus doronicoides Zone (Samples 495-3-4, 75-77 cm to 


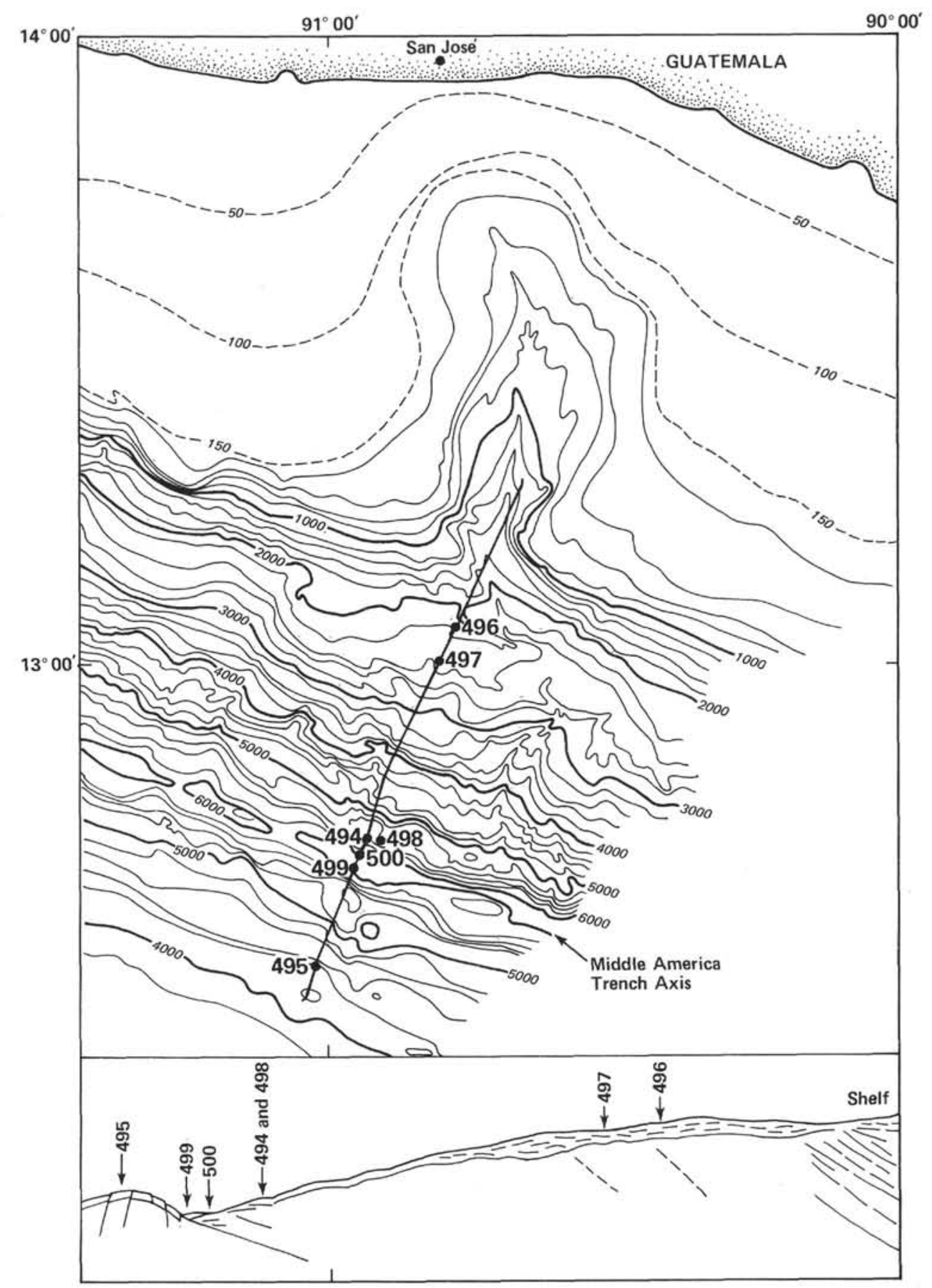

Figure 1. Leg 67 site locations.

495-6-4, 43-45). This part of the section includes many intervals barren of nannoplankton. The nannofossil abundance in the other intervals is low as a rule. Sample 495-3-5, 25-27 cm, containing Calcidiscus leptoporus, Gephyrocapsa oceanica, and small Gephyrocapsa and Emiliania, corresponds to the Gephyrocapsa oceanica Zone. Underlying samples (from 495-4-3, $100 \mathrm{~cm}$ ), lacking $G$. oceanica, belong to the Crenalithus doronicoides Zone.

Upper Pliocene. Discoaster brouweri Zone (Samples $495-7-1,90 \mathrm{~cm}$ to $495-11-3,28-30 \mathrm{~cm}$ ). The same hemipelagic mud recovered in this sample series contains very poor nannoflora: Discoaster brouweri, D. asymmetricus, D. pentaradiatus, D. decorus, and Ceratolithus rugosus. The sequence of occurrence (going downhole)-D. brouweri, $D$. pentaradiatus, and finally $D$. decorus-permits stratigraphic subdivision of the zone into the Calcidiscus macintyrei Subzone, the Discoaster pentaradiatus Subzone, and the Discoaster surculus/Discoaster tamalis Subzones.

Lower Pliocene and upper Miocene. Reticulofenestra pseudoumbilica/Amaurolithus tricorniculatus Zones (Samples 495-12-1, 60-61 cm to 495-13-3, 30-32 cm). The samples of this interval include earlier-mentioned 
Table 1. Zonal and age assignments for Leg 67 holes.

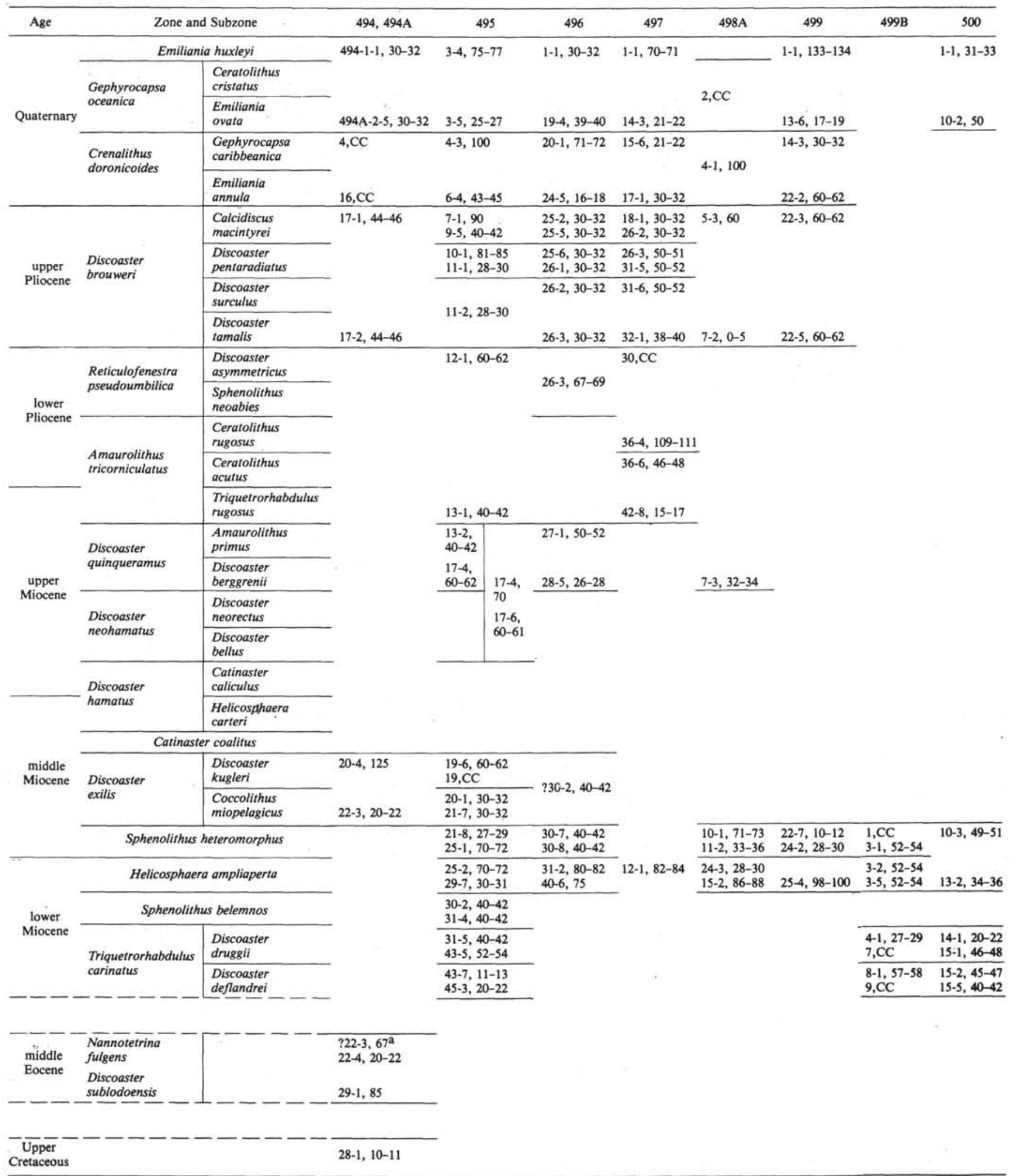

Note: Samples are indicated by core-section, interval in $\mathrm{cm}$.

Age assignment uncertain. 


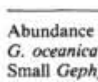

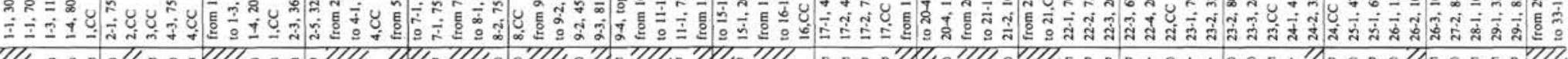

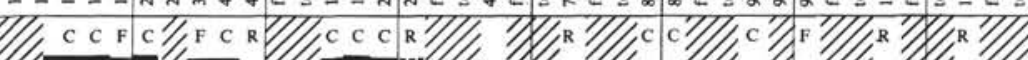

H. carteri
C. leptopon
E. ovate

E. ovata
E. annula
C. cristatus
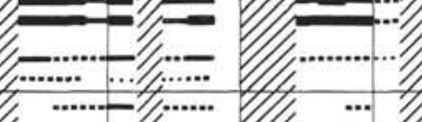

D. cristatus
D. aff. asymmetricus

D. deflandrei

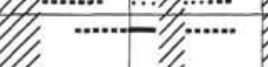

C. pelagicus s.1.
R. pseudioumbilic
Sphenonotithus sp.
C. floridanus

S. moriformis

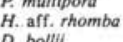

D. aff. kugleri

H. intermedia
C. macintyrei

C. nitescens
D. barbadiensis
C. eopelagicus

C. formosis

R. umbilica
H. . ophota
D. Iodoensis

D. lophoensis
D. sublodoensis

D. saipanensis
$D$. binodousus

D. binodosis
H. papillata
C. solitus
Colits

C. grandis

T. pulcheroides
D. gemmifer

D. delus
C. consuelus

$\frac{H . \text { seminulum }}{D . \text { strictus }}$

D. strictus
Chismolithus sp

2. bijugatus

Sphenolititus sp

C. inversus
Pontosphaera sp.

M. decussata

W. barnsesae
A. cymbiformis

A. cymbiformis
C. ehrenbergii

Legend:

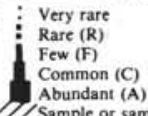

Figure 2. Nannoplankton distribution, Holes 494 and 494A

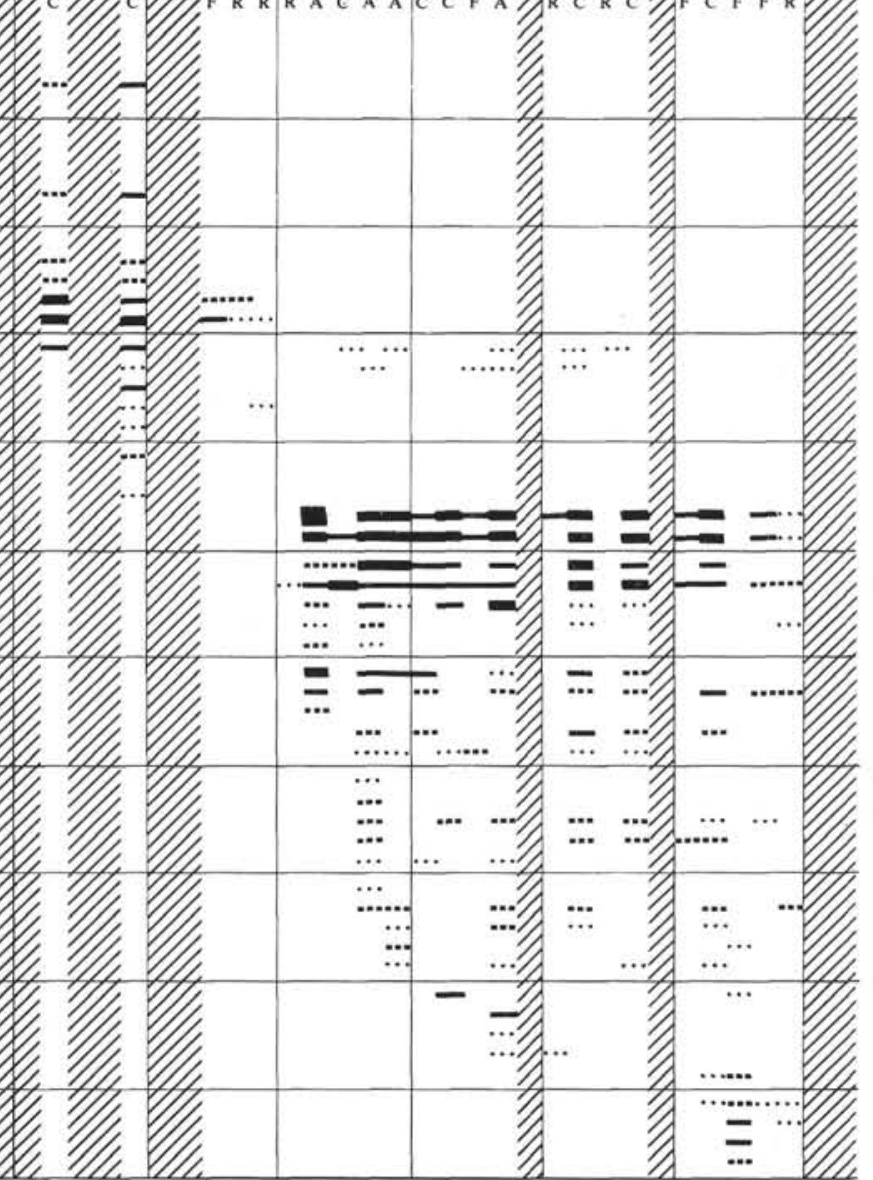


forms and Discoaster variabilis, D. surculus, Sphenolithus sp., and Ceratolithus acutus (very rare in Sample 495-12-6, 60-61 cm only). The interval corresponds with the Reticulofenestra pseudoumbilica Zone and at least in part with the Amaurolithus tricorniculatus Zone.

Upper Miocene. Discoaster quinqueramus Zone (Samples 495-13-4, 30-32 cm to 495-17-4, 60-61 cm; ?Samples $495-17-4,70 \mathrm{~cm}$ to $495-17-6,60-61 \mathrm{~cm})$. The assemblage of this zone is more variable, including Discoaster berggrenii, $D$. quinqueramus, Sphenolithus sp., and some others. Samples 495-17-4, $70 \mathrm{~cm}$ to $495-17-6,60-$ $61 \mathrm{~cm}$ contain specimens of $D$. loeblichi and possibly belong to the next zone-the Discoaster neohamatus Zone. Core 18 is barren. Beginning at Core 19 and below, calcareous nannofossil ooze and chalk contain abundant and rather diverse nannoplankton.

Middle Miocene. Discoaster exilis Zone, Sphenolithus heteromorphus Zone (Samples 495-19-6, 60-62 cm to 495-25-1, 70-72 cm). The upper part of the Discoaster exilis Zone contains D. kugleri, D. bollii, D. deflandrei, and some others. The lower part of the Zone begins at Sample 495-20-1, 30-32 cm and extends to Sample 49521-7, 30-32 cm. D. exilis and Coccolithus pelagicus s.l. (abundant) are the most typical taxa of the interval. These two parts belong to the Discoaster kugleri and the Coccolithus miopelagicus Subzones, respectively.

An assemblage resembling the last but containing Sphenolithus heteromorphus (few to common) and $D$. signus was assigned to the Sphenolithus heteromorphus Zone (Samples 495-21-8, 27-29 cm to 495-25-1, 70-72 $\mathrm{cm})$.

Lower Miocene. Helicosphaera ampliaperta Zone, Sphenolithus belemnos Zone, Triquetrorhabdulus carinatus Zone (Samples 495-25-2, 70-72 cm to 495-45-3, $20-22 \mathrm{~cm}$ ). The boundary between the Sphenolithus hetermorphus Zone and Helicosphaera ampliaperta Zone is determined by the last stratigraphic occurrence of $H$. ampliaperta. In Hole 495 and the other oceanic sites this level is poorly defined because of the extreme rarity of $H$. ampliaperta specimens.

The distinguishing feature of the Helicosphaera ampliaperta Zone assemblage is very rare specimens of zonal species in conjunction with $S$. heteromorphus and common Cyclicargolithus floridanus (Samples 495-25-2, $70-72 \mathrm{~cm}$ to $495-29-7,30-32 \mathrm{~cm}$ ).

In the Sphenolithus belemnos Zone (Samples 495-30$2,40-42 \mathrm{~cm}$ to $495-31-4,40-42 \mathrm{~cm}$ ) the zonal marker occurs and $S$. heteromorphus is absent.

At this Site and at Sites 499 and 500, the Triquetrorhabdulus carinatus Zone is represented only by its two upper subzones: the Discoaster druggii Subzone (Samples $495-31-5,40-42 \mathrm{~cm}$ to $495-43-5,52-54 \mathrm{~cm}$ ) and the Discoaster deflandrei Subzone (samples 495-43-7, 11-13 $\mathrm{cm}$ to $495-45-3,20-22 \mathrm{~cm}$ ). Stratigraphically important taxa of the first subzone include Triquetrorhabdulus carinatus, Orthorhabdulus serratus, and Discoaster druggii. Of these species, only $T$. carinatus is common to abundant in the Discoaster deflandrei Subzone.

The lower boundary of the Discoaster deflandrei Subzone coincides with the Miocene/Oligocene boundary.
The age of underlying basalt recovered in this hole is thus earliest Miocene.

\section{Site 496}

This site is located on the upper part of the Guatemala continental margin.

Quaternary. Emiliania huxleyi/Gephyrocapsa oceanica Zones, Crenalithus doronicoides Zone (Samples 496$1-1,30-31 \mathrm{~cm}$ to $496-24-5,16-18 \mathrm{~cm})$. The Quaternary section consists of predominantly dark olive gray biogenic mud and contains rare to abundant nannoplankton for the full length with only rare exceptions. The $G$. oceanica first occurrence divides this interval into Emiliania huxleyi/Gephyrocapsa oceanica Zones (Sample 496$1-1,30-32 \mathrm{~cm}$ to $496-19-4,39-40 \mathrm{~cm})$ and the Crenalithus doronicoides Zone (496-20-1, 71-72 cm to 496-24-5, $16-18 \mathrm{~cm})$.

Quaternary and older sediments in the hole are divided by a narrow interval (beginning at Core 25) without nannoflora. From Core 25 and below, dark olive gray mud and sandy mud are present.

Upper Pliocene. Discoaster brouweri Zone (Samples $496-25-2,30-32 \mathrm{~cm}$ to $496-26-3,30-32 \mathrm{~cm}$ ). Assemblage of this zone includes rare to common Discoaster brouweri and very rare to rare $D$. asymmetricus, $D$. pentaradiatus, and $D$. decorus. The two last forms allow division of the zone into the Calcidiscus macintyrei Subzone, the Discoaster pentaradiatus Subzone, and the Discoaster surculus/Discoaster tamalis Subzones.

Lower Pliocene. Reticulofenestra pseudoumbilica Zone (Sample 496-26-3, 67-69 cm). The single feature distinguishing nannoflora in this sample from upper Pliocene nannoflora is the occurrence of a few small specimens of Sphenolithus sp. The lower part of Core 26 (Sections 5 and 6) is barren of nannofossils.

Upper Miocene. Discoaster quinqueramus Zone (Samples 496-27-1, 50-52 cm to 496-28-5, 26-28 cm). The diverse and well preserved nannoplankton assemblage of these sediments contains Discoaster quinqueramus, $D$. berggrenii (common), D. intercalaris, $D$. aff. neorectus, D. surculus, D. pseudovariabilis, and some other forms.

Nannoplankton in Sections 496-29-1 to 496-30-6 are practically absent. Only Sample 496-30-2, 40-42 cm, which includes unique specimens of $D$. exilis and $\mathrm{Coc}$ colithus pelagicus s.1., may belong to the Discoaster exilis Zone, if the occurrence of zonal species there cannot be explained by contamination.

Upper Miocene. Sphenolithus heteromorphus Zone (Samples 496-30-7, 40-42 cm to 496-30-8, 40-42 cm). The assemblage of this interval includes Sphenolithus heteromorphus (rare to few) in combination with Discoaster exilis (few to common), D. aff. lidzii, and $D$. deflandrei.

Middle Miocene. Helicosphaera ampliaperta Zone (Sample 496-31-2, 80-82 cm to 496-40-6, $75 \mathrm{~cm}$ ). In contrast to Sites 495,499 , and 500 , the middle Miocene/lower Miocene boundary between the Sphenolithus heteromorphus Zone and the Helicosphaera ampliaperta Zone is quite distinct in the holes drilled on the landward slope of the Trench. Hole 496 samples of the 


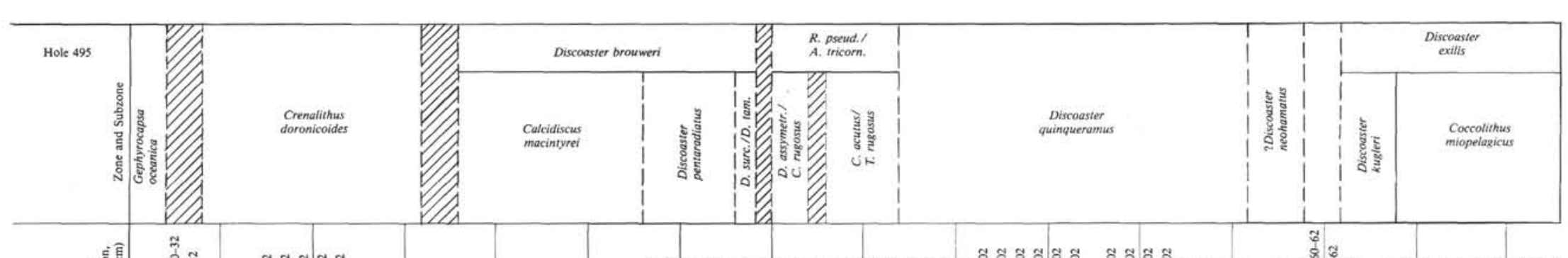

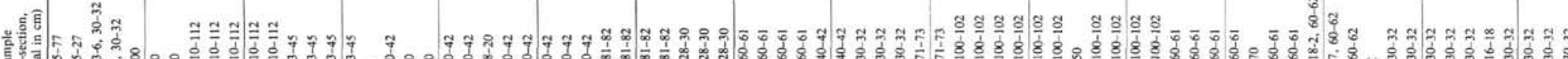

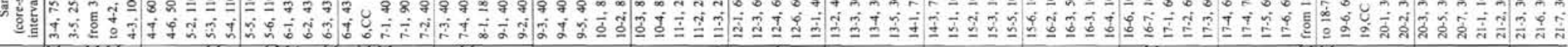

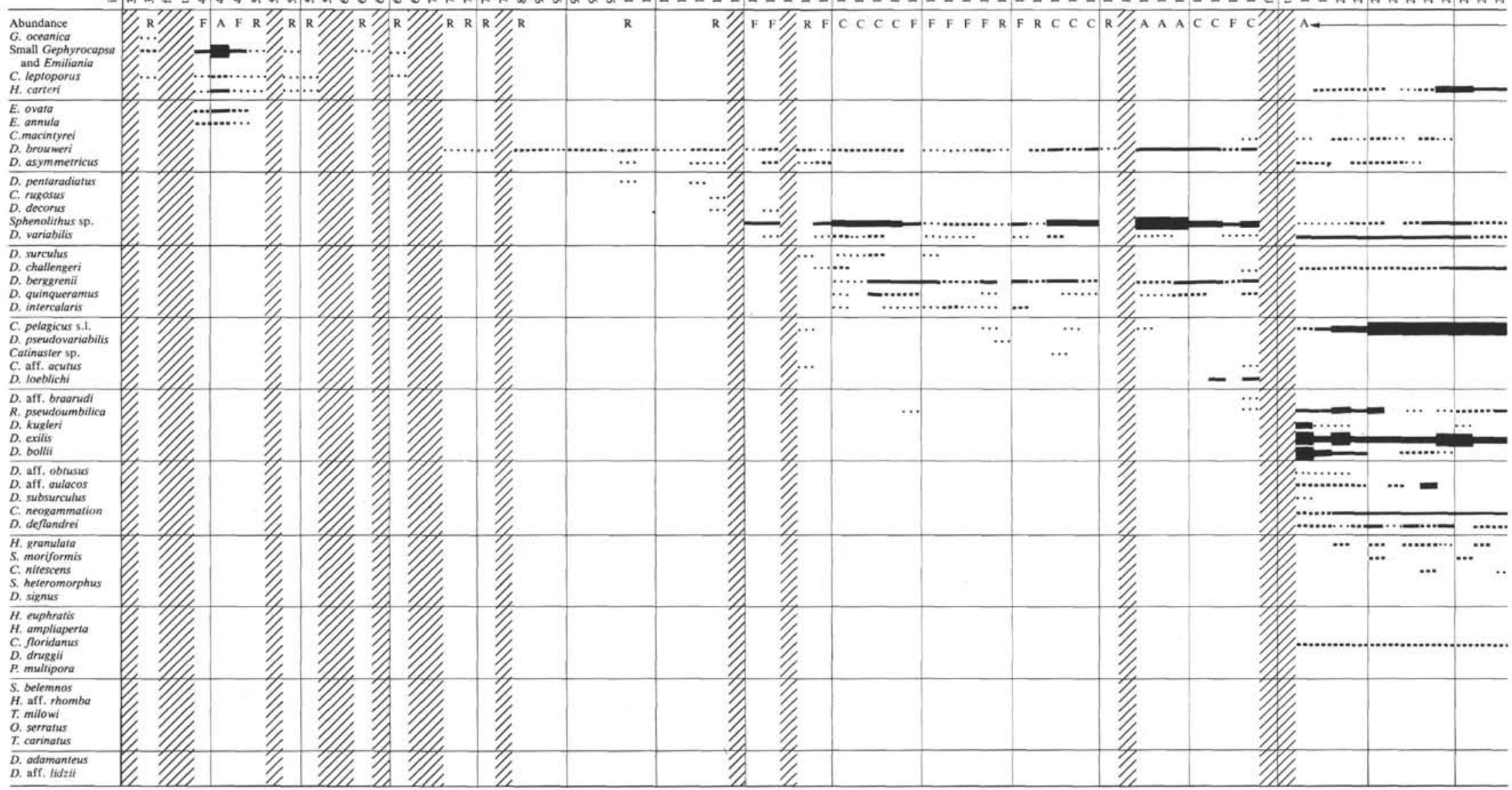

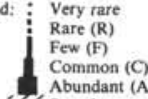

Abundant (A) 


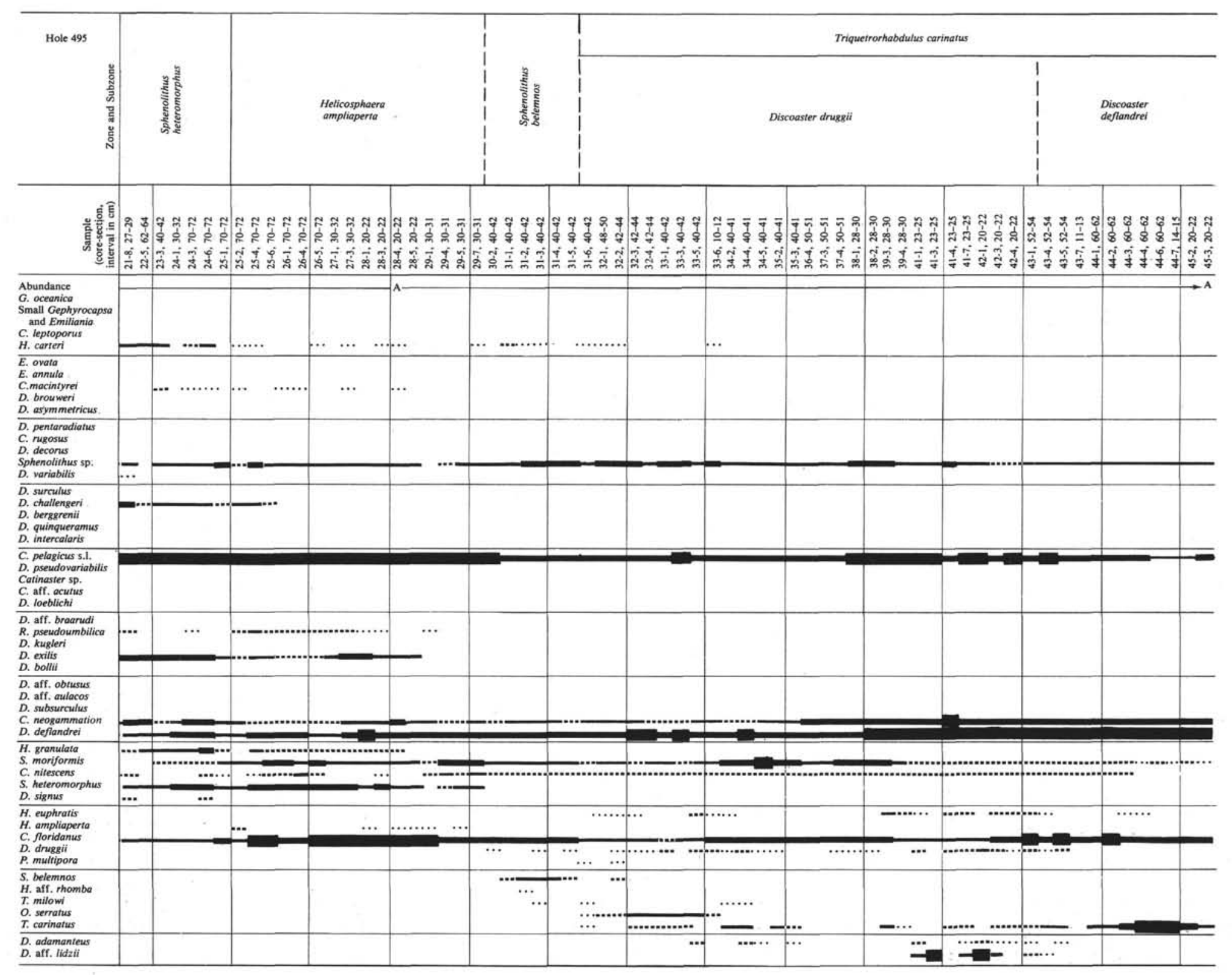

Figure 3. Nannoplankton distribution, Hole 495. 


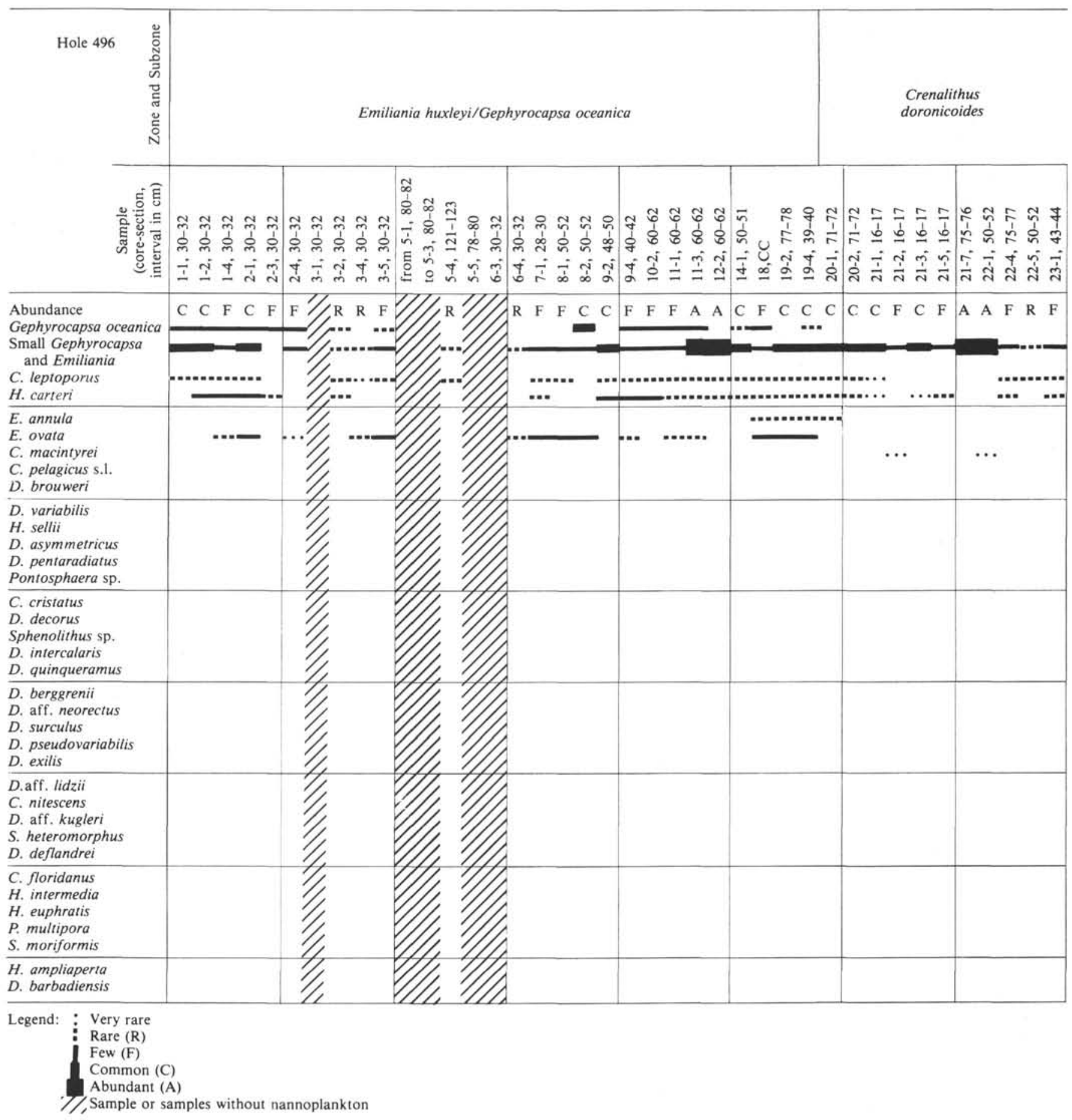

Figure 4. Nannoplankton distribution, Hole 496.

Helicosphaera ampliaperta Zone contain rare to common zonal species Sphenolithus heteromorphus, D. deflandrei, and some others. In addition, rare specimens of shallow-water Pontosphaera multipora were found in the lower part of the Zone.

\section{Site 497}

Site 497 is located on the midslope of the Trench, and its section is represented by mud and mudstone.

Quaternary. Emiliania huxleyi/Gephyrocapsa oceanica Zones, Crenalithus doronicoides Zone (Samples 497-
$1-1,70-71 \mathrm{~cm}$ to $497-17-1,30-32 \mathrm{~cm}$ ). Dark olive gray mud of Core 1 to Sample 497-14-3, 21-22 cm contain the standard assemblage of the Emiliania huxleyi/Gephyrocapsa oceanica Zones: G. oceanica, small Gephyrocapsa and Emiliania, and rare to abundant Calcidiscus leptoporus, Helicosphaera carteri, Emiliania ovata, and $E$. annula. Core 15 is barren. The lower Pleistocene Crenalithus doronicoides Zone is represented by sandy and pebbly mud. Most of the samples do not contain nannoplankton. Where present, the assemblage includes the forms just mentioned (without $G$. oceanica) and 


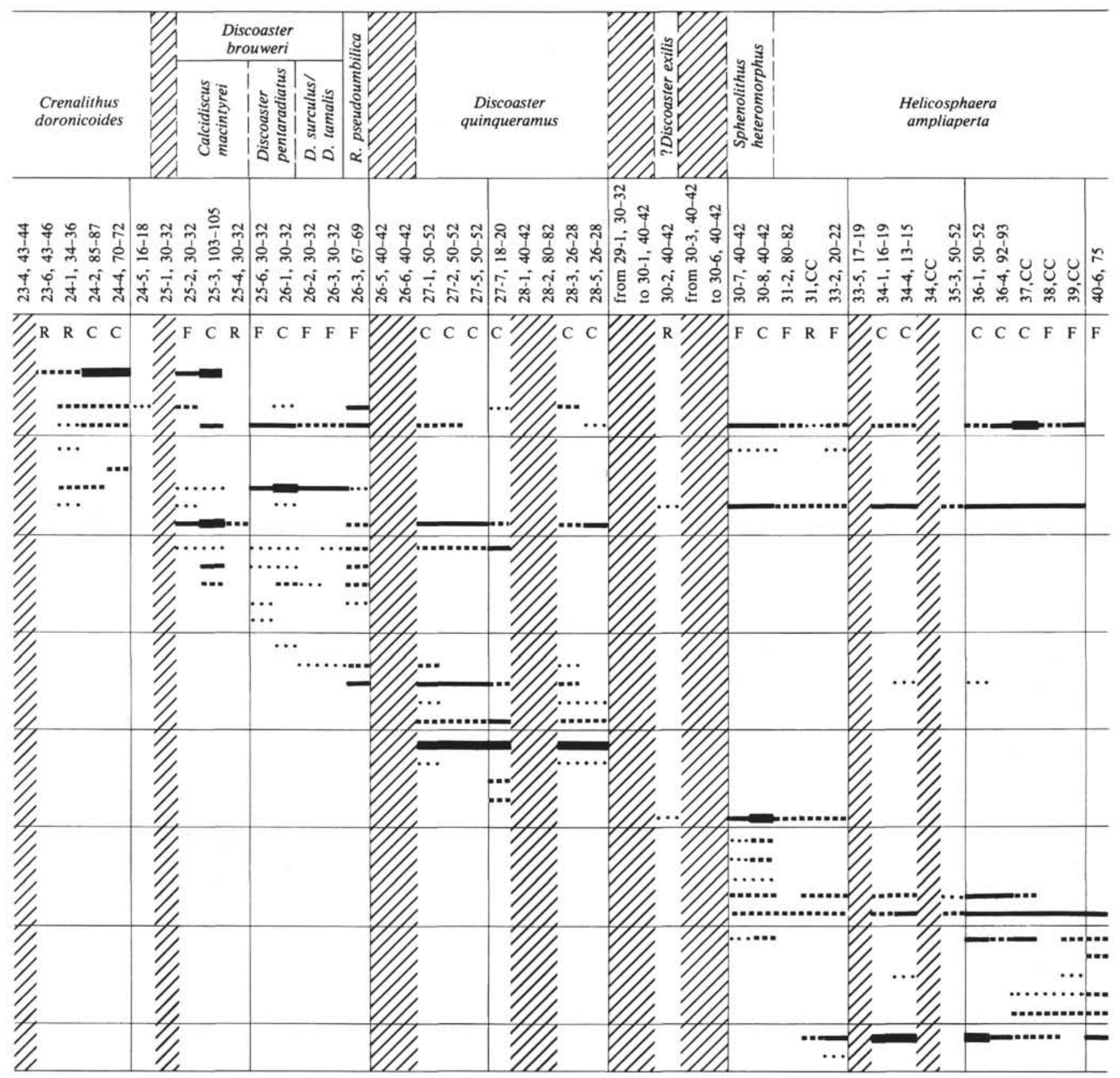

Figure 4. (Continued).

sporadic Calcidiscus pelagicus s.l., Coccolithus macintyrei, and Pontosphaera sp.

Upper Pliocene. Discoaster brouweri Zone (Samples $497-18-1,30-32 \mathrm{~cm}$ to $497-32-1,38-40 \mathrm{~cm}$ ). The upper Pliocene mudstone contains an assemblage with Discoaster brouweri (rare to common), D. asymmetricus, $D$. pentaradiatus, $D$. decorus, $D$. surculus, Helicosphaera sellii, $H$. carteri, and some other placoliths. On the basis of the sequence of appearance of marker species, the Zone is subdivided into the Calcidiscus macintyrei Subzone, the Discoaster pentaradiatus Subzone, and the Discoaster surculus/Discoaster tamalis Subzones.
Lower Pliocene and upper Miocene. Reticulofenestra pseudoumbilica/Amaurolithus tricorniculatus Zones (Samples 497-34-1, 50-52 cm to 497-42-8, 15-17 cm). D. brouweri, $D$. asymmetricus, $D$. pentaradiatus, $D$. decorus, $D$. surculus, $D$. berggrenii, $D$. variabilis, $D$. intercalaris, D. challengeri, Sphenolithus sp. (rare to abundant), sporadic Ceratolithus acutus, Amaurolithus tricorniculatus, and A. amplificus are present in this interval. The ceratoliths, on which the high-resolution subzonal scale for this age interval is based, are practically absent. Nevertheless, the occurrence of $C$. acutus in Sample 497-36-6, 46-48 cm determines its age and the age of underlying samples as not younger than the Cera- 


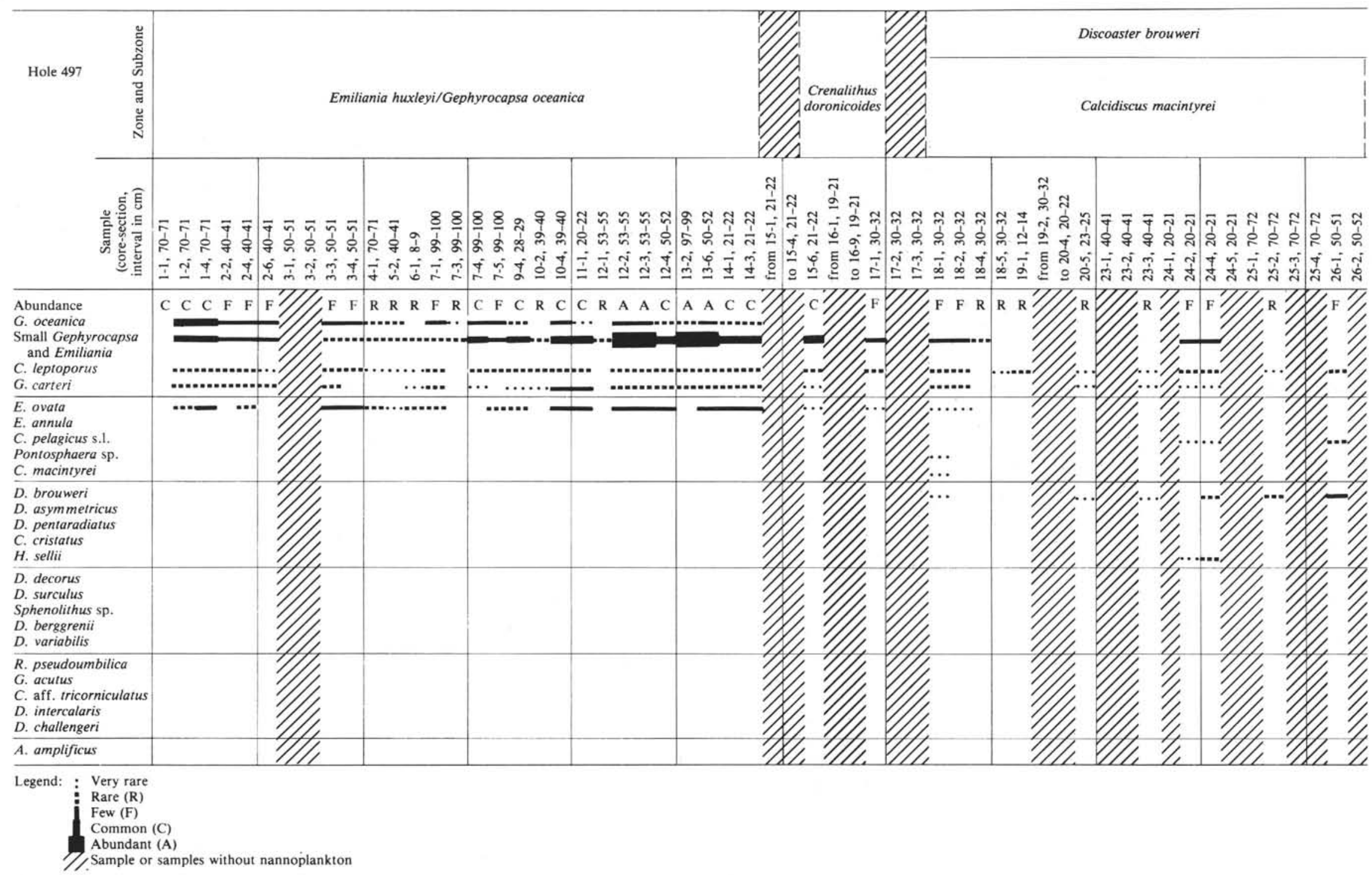




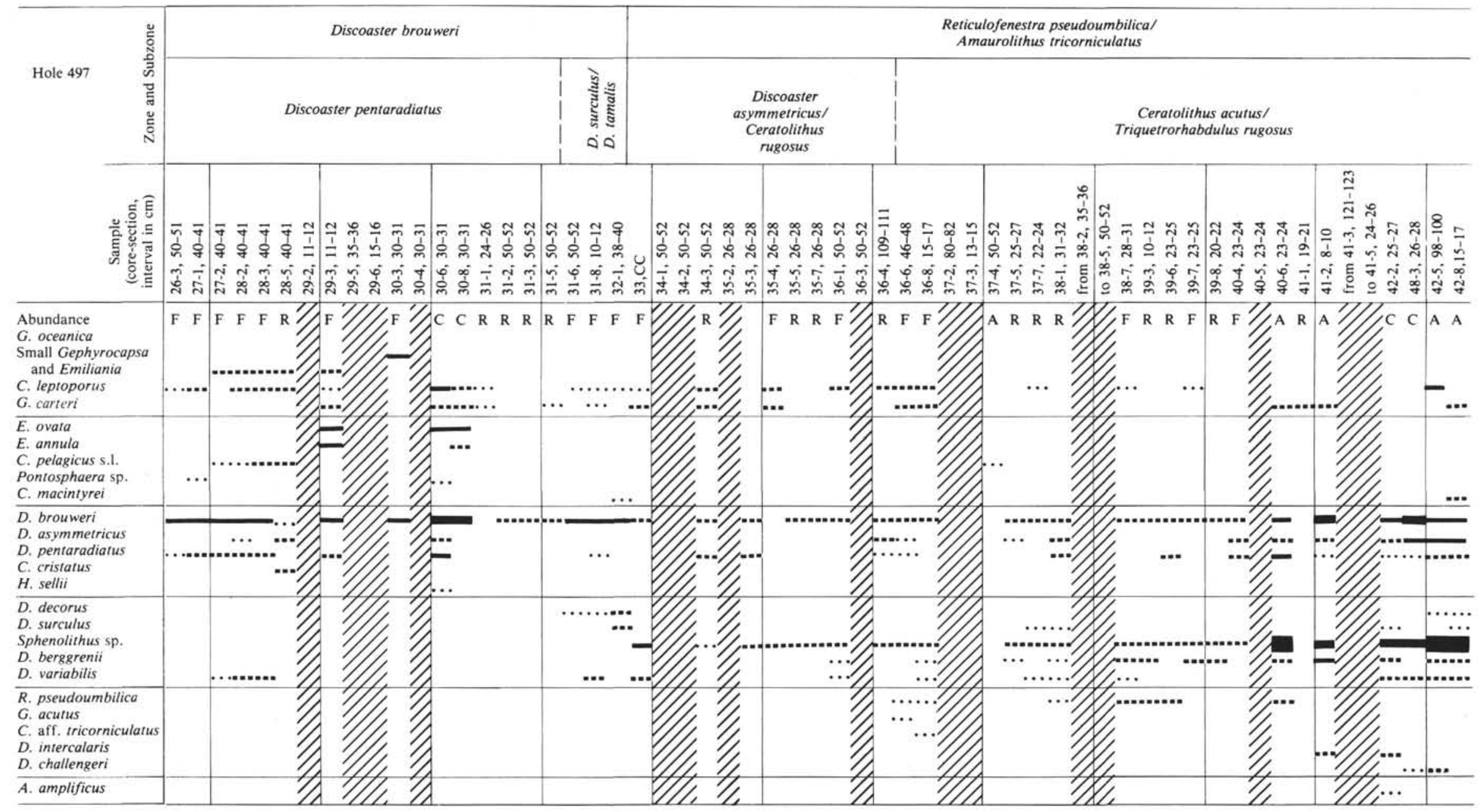

Figure 5. Nannoplankton distribution, Hole 497. 


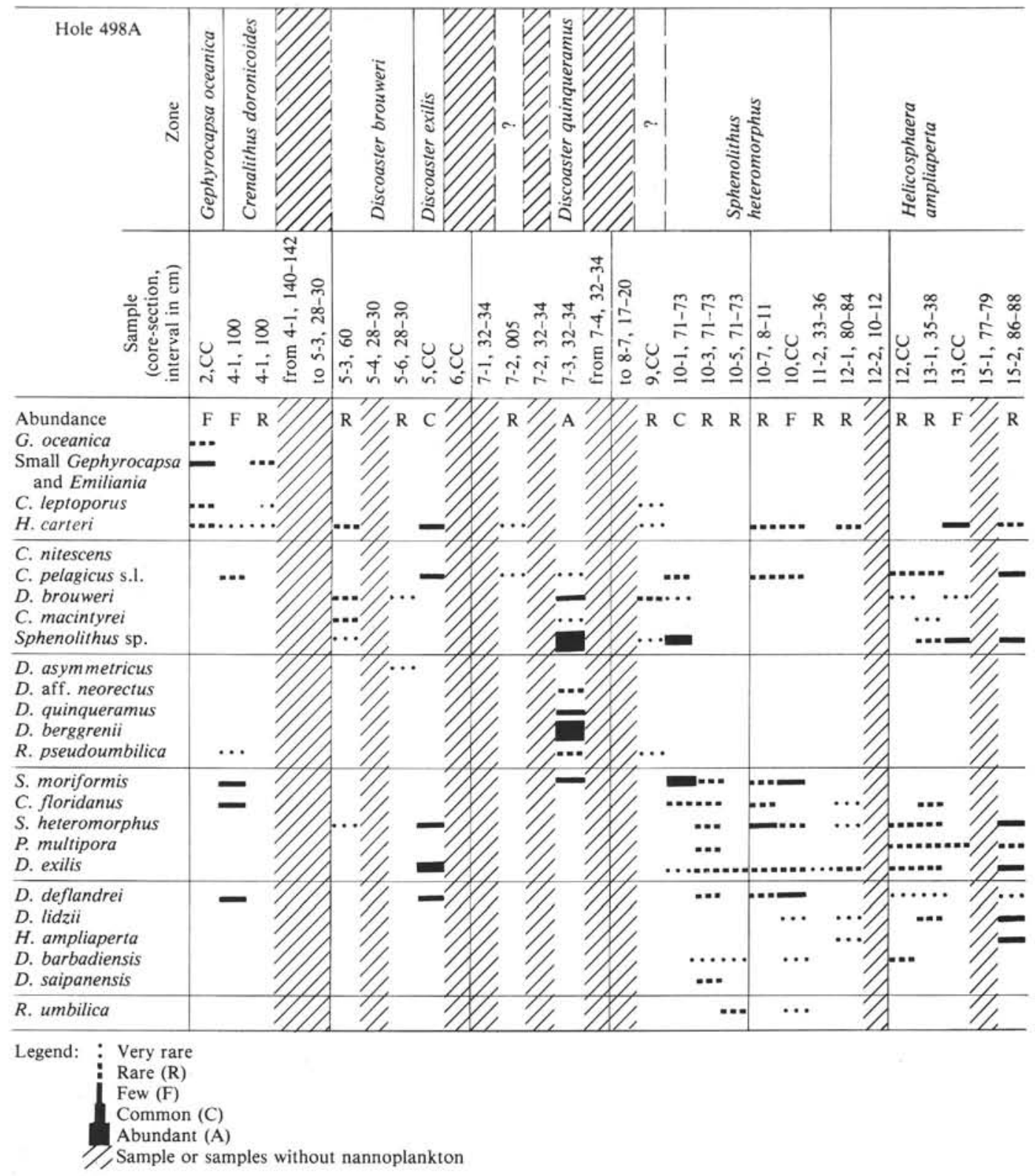

Figure 6. Nannoplankton distribution, Hole 498A.

tolithus acutus Subzone. A. amplificus, found in the Sample 497-42-2, 25-27 cm, occurs from the Triquetrorhabdulus rugosus Subzone to the Discoaster quinqueramus Zone. As the zonal form of the latter was not recorded at Site 497, it is most likely that the Hole ended in the Amaurolithus tricorniculatus Zone.

\section{Site 498 (Holes 498 and 498A)}

Situated at the foot of the landward slope about $2 \mathrm{~km}$ east of Site 494, Site 498 was selected in the hope of improving the poor recovery rate at Site 494 .

Quaternary. Gephyrocapsa oceanica Zone, Crenalithus doronicoides Zone (Samples 498A-2,CC and 498A-4$1,100 \mathrm{~cm}$ ). The first 212 meters of the section were washed and sampled every 50 meters only. As expected, this interval belongs to the Quaternary.
From Sample 498A-5-1, 28-30 cm to Sample 498A$8-6,26-28 \mathrm{~cm}$ nannoplankton are rare.

Upper Pliocene. Discoaster brouweri Zone (Samples $498 \mathrm{~A}-5-3,60 \mathrm{~cm}$ and 498A-5-6, 28-30 cm). These two samples contain Helicosphaera carteri, Calcidiscus macintyrei, Discoaster brouweri, D. asymmetricus, and reworked Sphenolithus heteromorphus and Sphenolithus sp. The reworked middle Miocene assemblage with $S$. heteromorphus, $D$. exilis, and $D$. deflandrei are first encountered in Sample 498A-5, CC, although other microfossil groups indicate reworking in Core 498A-4 (see Site 498 report).

Samples 498A-6, CC to 498A-7-2, 32-34 cm are barren. This interval may belong to the lower Pliocene.

Upper Miocene. Discoaster quinqueramus Zone (Sample 498A-7-3, 32-34 cm). An excellent assemblage with 


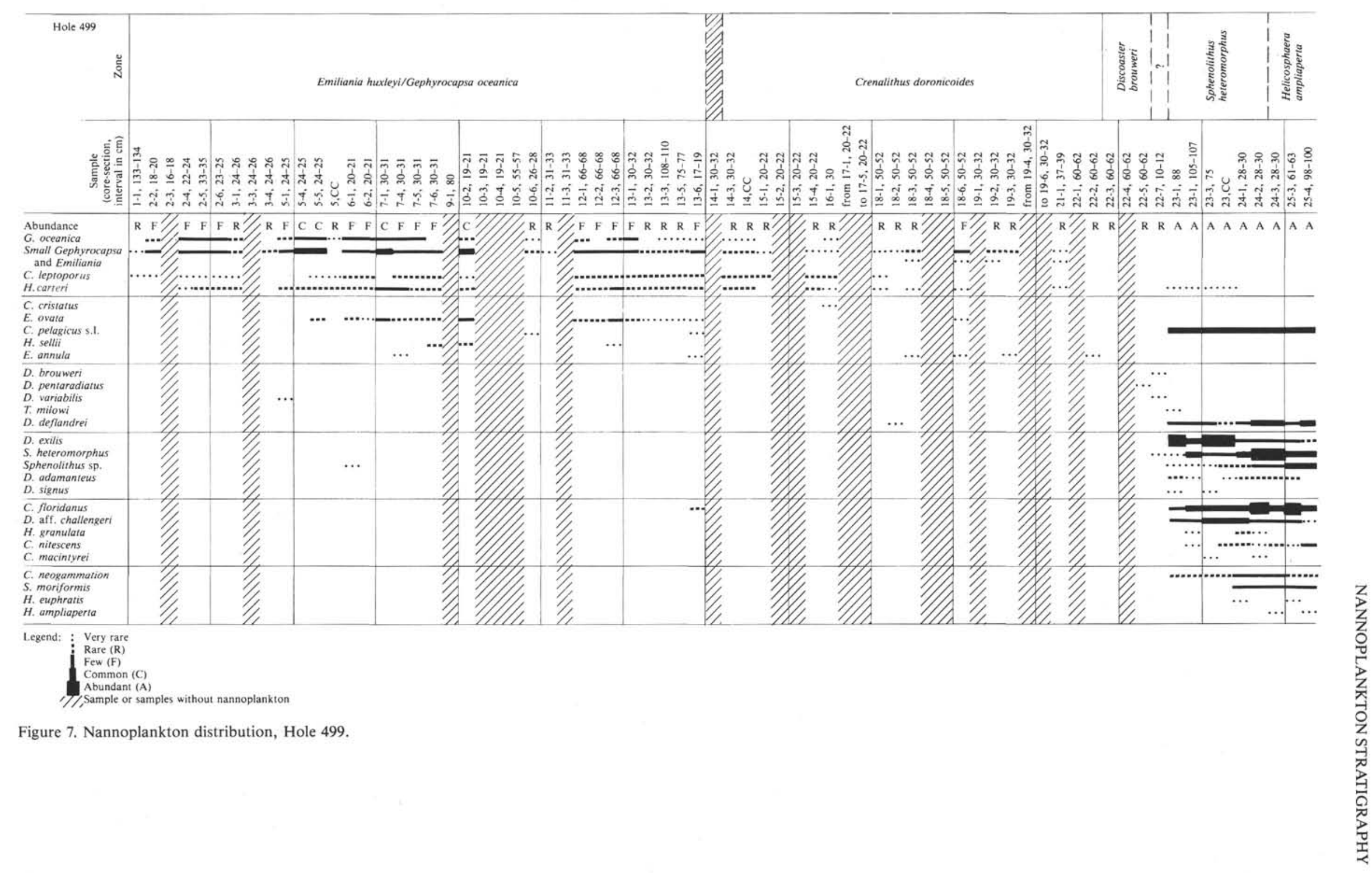




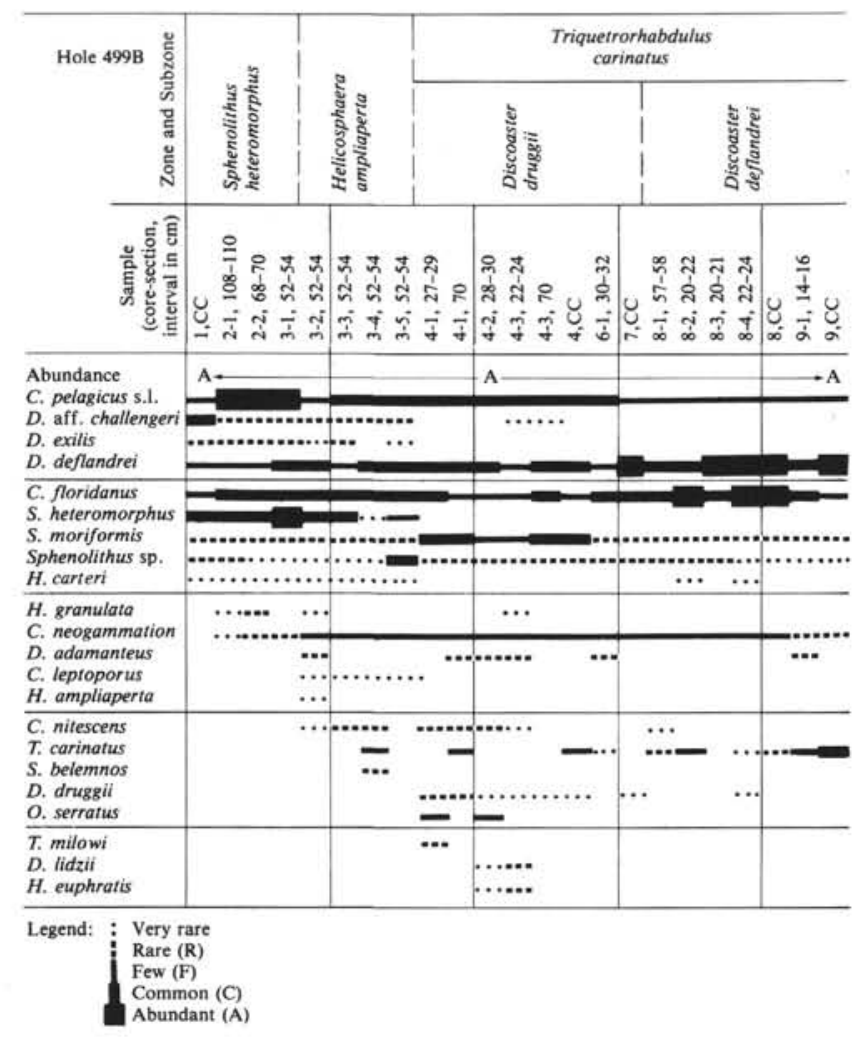

Figure 8. Nannoplankton distribution, Hole 499B.

zonal species $D$. berggrenii (abundant), $D$. brouweri, $D$. aff. neorectus, and Sphenolithus sp. (abundant) was found in this single sample.

Sample 498A-9, CC contains poor nannoflora with $C$. leptopora, Helicosphaera carteri, D. brouweri, Reticulofenestra pseudoumbilica, and Sphenolithus sp. All these taxa occur across a wide stratigraphic range.

Upper Miocene. Sphenolithus heteromorphus Zone (Samples 498A-1-10, 71-73 cm to 498A-12-2, 33-36 $\mathrm{cm})$. Mudstone of this Zone includes zonal species $D$. exilis, D. deflandrei, Cyclocargolithus floridanus, S. moriformis, and some other species.

Lower Miocene. Helicopontosphaera ampliaperta Zone (Samples 498A-12-2, 10-12 cm to 498A-15-2, 86$88 \mathrm{~cm}$ ). This assemblage is very similar to the upper Miocene assemblage but includes Helicosphaera ampliapert $a$ and shallow-water species Pontosphaera multipora.

\section{Site 499 (Holes 499, 499A, and 499B)}

The site is located on the floor of the Trench. Quaternary and upper Pliocene cores are represented by muddy and sandy turbidite and underlying diatomaceous mud.

Quaternary. Emiliania huxleyi/Gephyrocapsa oceanica Zones, Crenalithus doronicoides Zone (Core 499-1, top, to Sample 499-5-1, 133-135 cm; Samples 499A-1-1, $133-134 \mathrm{~cm}$ to $499 \mathrm{~A}-22-2,60-62 \mathrm{~cm}$ ). The turbidite member belongs to Holocene and upper Pleistocene Emiliania huxleyi/Gephyrocapsa oceanica Zones (to Sample 499-5-1, 133-135 cm and Sample 499A-13-6, 17-19 cm). The assemblage consists of $C$. leptopora, Helicosphaera carteri, G. oceanica, small Gephyrocapsa oceanica and
Emiliania (rare to common), E. ovata, and sporadical E. annula, Ceratolithus cristatus, Coccolithus pelagicus s.l. The nannoflora is rare in the lower Pleistocene Crenalithus doronicoides Zone (Samples 499A-14-1, $30-32 \mathrm{~cm}$ to $499 \mathrm{~A}-22-2,60-62 \mathrm{~cm}$ ), which covers practically all the mud members of the section. The taxa list is identical to the overlying zone but lacks $G$. oceanica.

Upper Pliocene. Discoaster brouweri Zone (Samples $499 \mathrm{~A}-22-3,60-62 \mathrm{~cm}$ to $499 \mathrm{~A}-22-7,10-12 \mathrm{~cm}$ ). The basal core of the mud unit contains very rare specimens of $D$. brouweri and D. pentaradiatus (Sample 499A-22$5,60-62 \mathrm{~cm}$ ). This core belongs to the Calcidiscus macintyrei Subzone and the Discoaster pentaradiatus Subzone.

Below Pleistocene and Pliocene mud, nannofossil ooze and chalk were recovered in Holes 499A and 499B.

Middle Miocene. Sphenolithus heteromorphus Zone (Samples 499A-23-1, $88 \mathrm{~cm}$ to 499A-24-2, 28-30 cm; Samples 499B-1,CC to 499B-3-1, 52-54 cm). These two series of samples include excellent assemblages with zonal species $D$. exilis, $D$. deflandrei, Cyclicargolithus floridanus, and other forms.

Lower Miocene. Helicosphaera ampliaperta Zone, Triquetrorhabdulus carinatus Zone (Samples 499A-24-3, 28-30 cm to 499A-25-4, 98-100 cm; Samples 499B-3-2, $52-54 \mathrm{~cm}$ to $499 \mathrm{~B}-9, \mathrm{CC})$. As in previous oceanic sites the upper limit of the Helicosphaera ampliaperta Zone (Samples 499A-24-3, 28-30 cm to 499A-25-4, 98-100 $\mathrm{cm}$; Samples 499B-3-2, 52-54 cm to 499B-5-5, 52-54 $\mathrm{cm}$ ) is approximate because of marker-species rarity. It is quite possible that the true position of this level is higher.

The Sphenolithus belemnos Zone was not found in Hole 499B. Its absence there is easier to explain as a result of reduced thickness rather than as a hiatus.

The Triquetrorhabdulus carinatus Zone (Samples 499B-4-1, 27-29 cm to 499B-9,CC) ends at the basalt/ sediment contact. The stratigraphically important taxa of the Discoaster druggii Subzone include Triquetrorhabdulus carinatus, Orthorhabdulus serratus, and $D$. druggii. The Discoaster deflandrei Subzone is notable for the absence of $D$. druggii.

\section{Site 500 (Holes 500, 500A, 500B, 500C)}

This site is situated at the juncture of the Trench landward slope and the Trench floor. The lithostratigraphic sequence is like that at Site 499 , that is, turbidite, diatomaceous mud, and then nannofossil chalk.

Quaternary. Emiliania huxleyi/Gephyrocapsa oceanica Zones (Samples 500-1-1, 31-33 cm to 500-10-2, 50 $\mathrm{cm})$. Turbidites comprise this interval. The nannoflora is similar to that at Site 499, with the exception of sporadic occurrences of Pontosphaera multipora.

The mud unit recovered in Holes 500A and 500B (Samples 500A-1, CC [3-5 cm]; 500-2, CC [7-8 cm]; 500B$1-6,84-86 \mathrm{~cm}$; and 500B-2-6, 19-21 cm) is barren of nannofossils. By analogy with Site 499 , the age of the mud may be defined as early Pleistocene and Pliocene.

Middle and lower Miocene. Sphenolithus heteromorphus/Helicosphaera ampliaperta Zones, Triquetrorhabdulus carinatus Zone (Samples 500-10-3, 49-51 cm to 


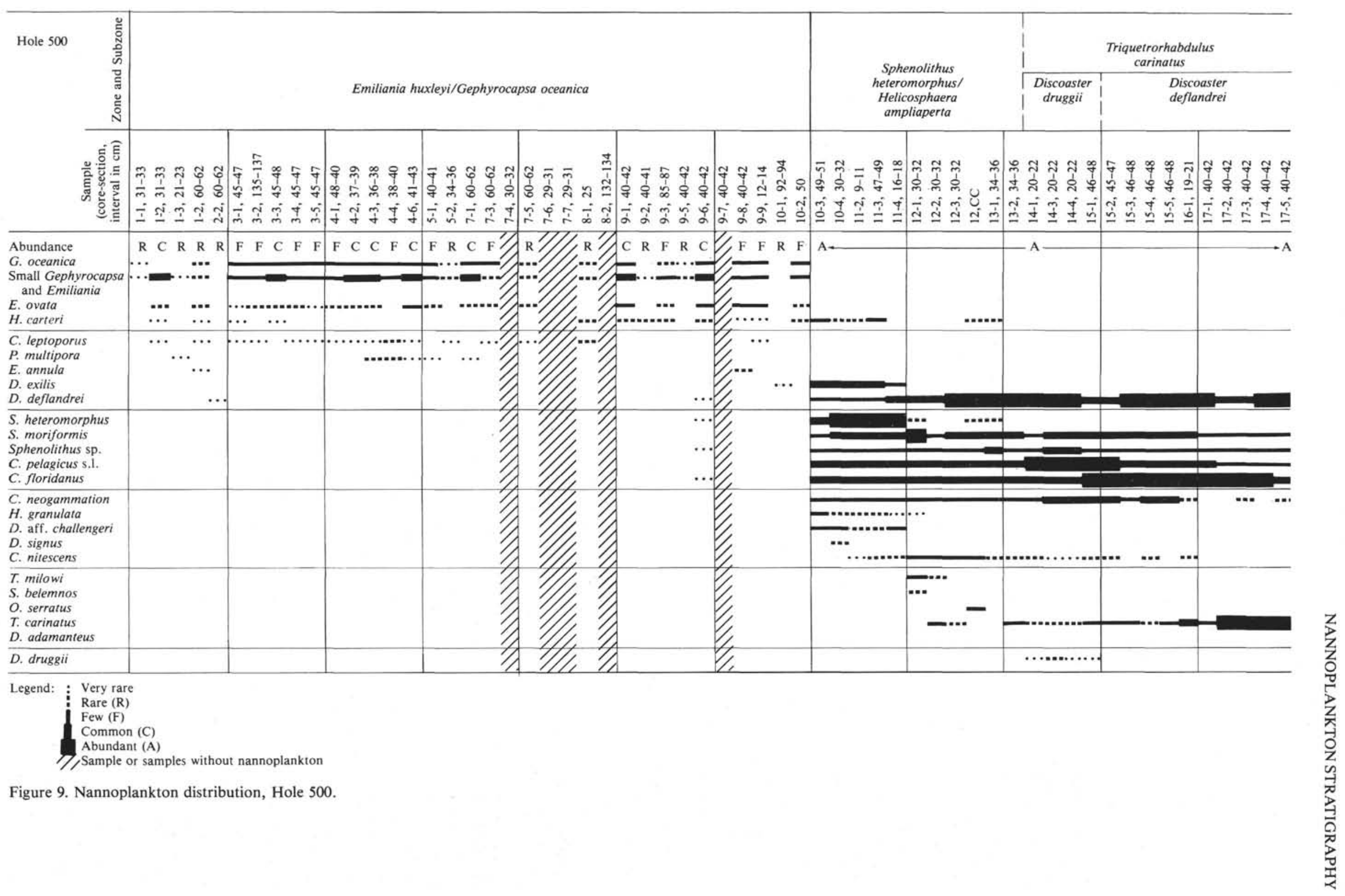


$500-17-5,40-42 \mathrm{~cm})$. The stratigraphic distribution of nannoplankton in the Miocene chalk is generally the same as at Site 499 . The unsampled interval between Samples 500-13-2, 34-36 cm and 500-14-1, 20-22 cm may correspond to the lower part (or full?) Helicosphaera ampliaperta Zone as well as the Sphenolithus belemnos Zone.

\section{REFERENCES}

Bukry, D., 1973. Low-latitude coccolith biostratigraphic zonation. In Edgar, N. T., Saunders, J. B., et al., Init. Repts. DSDP, 15: Washington (U.S. Govt. Printing Office), 685-703.

1975. Coccolith and silicoflagellate stratigraphy, Northwestern Pacific Ocean, Deep Sea Drilling Project Leg 32. In Larson, R. L., Moberly, R., et al., Init. Repts. DSDP, 32: Washington (U.S. Govt. Printing Office), 677-701. 


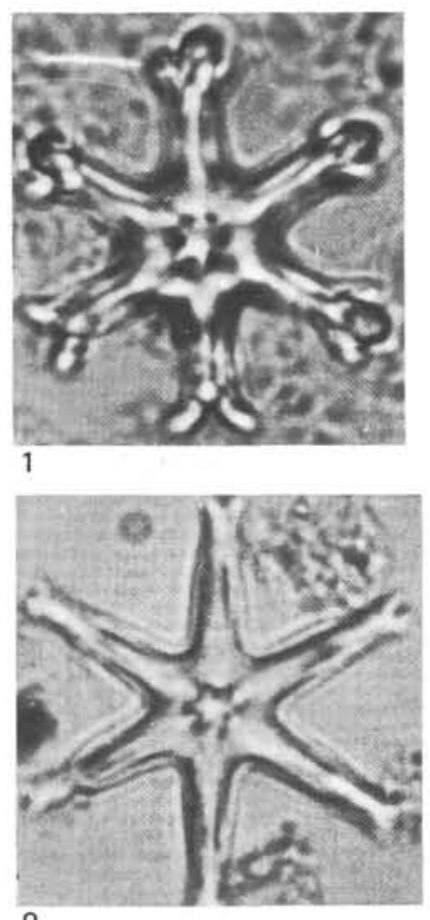

9

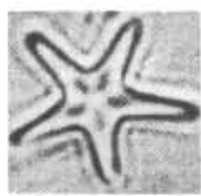

14
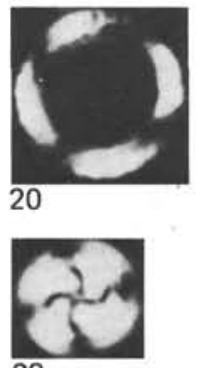

28

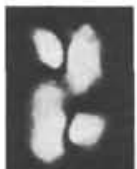

30

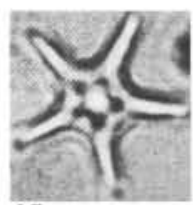

15

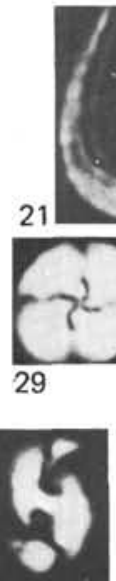

31

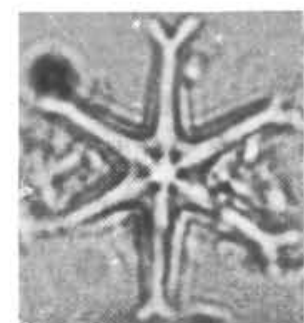

2
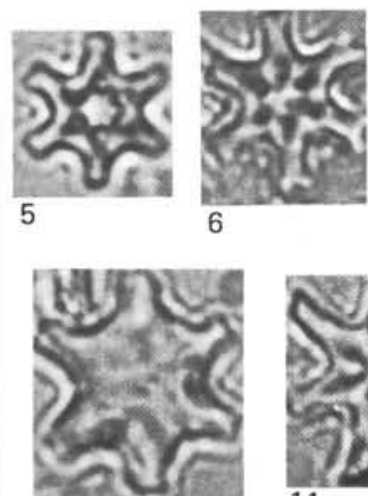

10

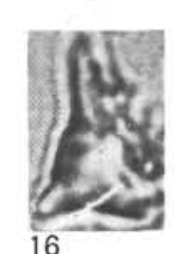

11
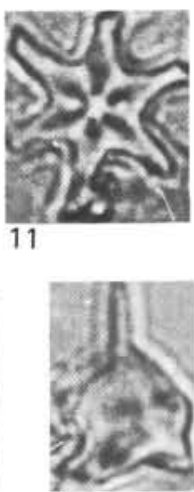

17
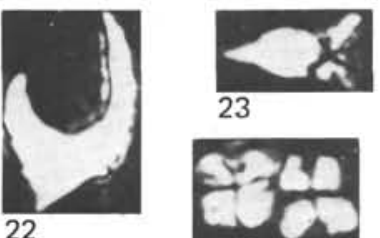

23
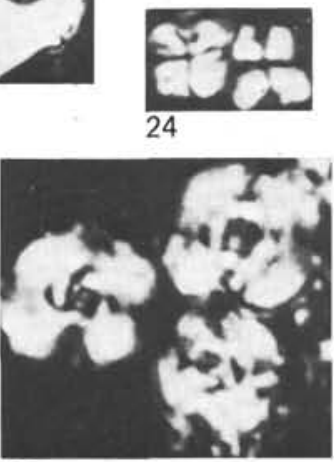

33
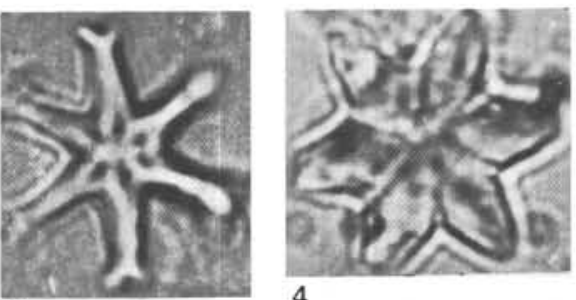

4

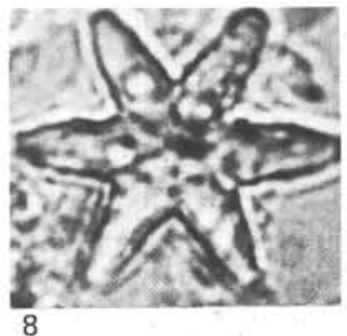

8

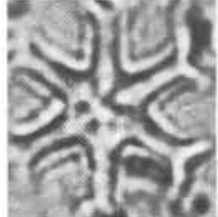

12

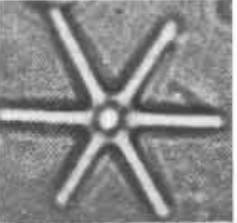

13

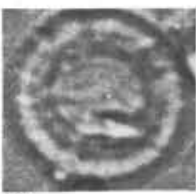

19

Plate 1. (All specimens are magnified $\times 2000$.) 1. Discoaster surculus Martini and Bramlette. Sample 497-42-5, 98-100 cm. 2. Discoaster exilis Martini and Bramlette. Sample 495-19-6, 60-62 cm. 3. Discoaster variabilis Martini and Bramlette. Sample 495-17-6, 60-61 cm. 4, 7, 8. Discoaster druggii Bramlette and Wilcoxon. Sample 495-31-5, 40-42 cm. 5, 6. Discoaster bollii Martini and Bramlette. Sample 495-19-6, 60-62 cm. 9. Discoaster decorus Bukry. Sample 497-32-1, 38-40 cm. 10. Discoaster kugleri Martini and Bramlette. Sample 495-19-6, 60-62 cm. 11. Discoaster loeblichi Bukry. Sample 495-17-6, 60-61 cm. 12. Discoaster challengeri Bramlette and Riedel. Sample 497-42-5, 98-100 cm. 13. Discoaster aff. braarudii Bukry. Sample 495-17-6, 60-61 cm. 14, 15. Discoaster berggrenii Bukry. Sample 495-17-6, 60-61. 16-18. Orthorhabdulus serratus Bramlette and Wilcoxon. Sample 495-31-5, 40-42 cm. 19, 20. Coronocyclus nitescens (Kamptner) Bramlette and Wilcoxon. Sample 500-12-1, 30-32 cm. 21. Amaurolithus aff. tricorniculatus (Gartner) Gartner and Bukry. Sample 497-36-8, 15-17 cm. 22. Amaurolithus amplificus (Bukry and Percival) Gartner and Bukry. Sample 497-42-2, 25-27 cm. 23, 25, 26. Sphenolithus heteromorphus Deflandre. Sample 496-30-8, 41-43 cm. 24. Sphenolithus moriformis (Bronnimann and Stradner) Bramlette and Wilcoxon. Sample 500-12-1, 30-32 cm. 27. Sphenolithus belemnos Bramlette and Wilcoxon. Sample 495-31-4, 40-42 cm. 28, 29. Cyclicargolithus floridanus (Roth and Hay) Bukry. Sample 496-30-8, 41-42 cm. 30. Helicosphaera carteri Hay and Mohler. Sample 497-30-6, 30-31 cm. 31. Helicosphaera sellii Bukry and Bramlette. Sample 497-30-6, 30-31. 32. Helicosphaera ampliaperta (Bramlette and Wilcoxon) Bukry. Sample 496-34-4, 13-15 $\mathrm{cm}$. 33. Group of Cyclococcolithina neogammation (Bramlette and Wilcoxon) Wilcoxon. Sample 500-14-4, 20-22 cm. 34. Group of Triquetrorhabdulus carinatus Martini. Sample 500-17-3, 40-42 cm. 